\title{
Elemen Smart Library pada Interior Perpustakaan Perguruan Tinggi
}

Arifah Nur Syahida ${ }^{1}$ | Ratri Wulandari ${ }^{1}$ | Vika Haristianti ${ }^{1}$

${ }^{1}$ Program Studi Desain Interior, Fakultas Industri Kreatif, Universitas Telkom, Bandung, Jawa Barat, Indonesia

Corresponding Author :email: wulandarir@telkomuniversity.ac.id

\begin{abstract}
ABSTRAK
Penelitian ini bertujuan mengetahui elemen dan konsep smart library dengan mengevaluasi kehadiran elemen dan konsep smart library pada empat perpustakaan perguruan tinggi di Kota Bandung. Metode yang digunakan adalah metode kualitatif deskriptif dengan pengambilan data melalui observasi dan wawancara. Diketahui bahwa dari 7 elemen kelengkapan smart library, hanya 4 yang teraplikasi, dengan elemen robotik dan rak buku cerdas sebagai elemen yang belum dihadirkan. Sementara itu, dari 4 konsep smart library, 3 telah teraplikasi, dengan konsep smart place belum diaplikasikan karena terkait dengan smart building. Disimpulkan bahwa elemen smart library yang teraplikasi di Indonesia antara lain pengaplikasiaan RFID, 24 jam selfservice, drop dan sortir buku, loker cerdas dan pemesanan ruang menggunakan sistem.
\end{abstract}

Kata Kunci: Perpustakaan, Perpustakaan Perguruan Tinggi, Smart Library

\begin{abstract}
This study aimed to identify the elements and concepts of smart libraries by evaluating the presence of elements and concepts of smart libraries in four university libraries in Bandung. The method used was descriptive qualitative method with data collection through observation and interviews. It was known that of the 7 completeness elements of the smart library, only 4 are applied, with robotic elements and smart bookshelves as elements that have not been presented. Meanwhile, of the 4 smart library concepts, 3 have been applied, with the concept of smart place not being applied because it is related to smart building. It is concluded that the smart library elements, that are applied in Indonesia, include the application of RFID, 24 hours self-service, book drop and sorting, smart lockers, and space booking through system.
\end{abstract}

Keywords: Library, University library, Smart Library

\section{PENDAHULUAN}

Perpustakaan Perguruan Tinggi merupakan salah satu instansi yang berperan sebagai pendukung pembelajaran untuk tiap program studinya dengan menyediakan materi pendukung serta strategi pembelajaran untuk untuk mendukung kegiatan akademik. Berdasarkan Peraturan Kepala Perpustakaan Nasional Republik Indonesia Nomor 13 Tahun 2017, menyebutkan bahwa Perpustakaan Perguruan Tinggi harus melingkupi standar diantaranya perpustakaan harus memiliki standar koleksi, sarana prasarana, pelayanan, tenaga, penyelenggaraan, pengelolaan Perpustakaan Perguruan Tinggi yang dapat memberikan fasilitas proses pembelajaran tridharma perguruan tinggi, yang diantaranya meliputi pendidikan, penelitian dan pengabdian kepada masyarakat serta berperan untuk meningkatkan prestasi akademik. Peraturan tersebut berlaku untuk Perguruan Tinggi negeri atau swasta yang terdiri atas universitas, insititut, sekolah tinggi, politeknik, dan akademik.

Di dalam perpustakaan fisik, pengunjung melakukan kegiatan pencarian buku pada katalog, memilah dan membaca buku, meminjam dan mengembalikan buku, melakukan desk research, belajar, mengerjakan tugas-tugas, berdiskusi, menghadiri kegiatan yang diadakan oleh perpustakaan seperti seminar, bedah buku, dan berbagai kegiatan literasi lainnya. Perkembangan teknologi dan informasi merupakan salah satu faktor yang dapat memengaruhi minat baca masyarakat Indonesia. Masyarakat pun mulai meninggalkan buku-buku dan media informasi di perpustakaan dan beralih untuk mengakses informasi melalui teknologi (Daniel et al., 2018). Daniel et al (2018) mengutip data Perpustakaan Nasional, bahwa sebanyak 132,7 juta masyarakat Indonesia tercatat sebagai pengguna internet. Untuk meningkatkan minat baca masyarakat di perpustakaan pada era digital, perlu adanya fasilitas yang didukung dengan teknologi inovatif serta memiliki suasans yang dapat menginspirasi 
dan memotivasi masyarakat penggunanya (Daniel et al., 2018).

Berdasarkan survey dan observasi penulis, beberapa Perpustakaan Perguruan Tinggi di Indonesia, khususnya di Kota Bandung, telah memiliki fasilitas cerdas dan diklaim sebagai smart library. Beberapa perpustakaan tersebut diantaranya Perpustakaan Universitas Telkom (Open Library Tel-U/Oplib Tel-U), Perpustakaan Universitas Islam Negeri Sunan Gunung Djati Kampus 1 Kota Bandung (Perpustakaan UIN Bandung), Perpustakaan Institut Teknologi Bandung (ITB), dan Perpustakaan Universitas Widyatama. Akan tetapi, benarkah perpustakaan tersebut di atas telah memenuhi kelengkapan dari sebuah smart library sesuai dengan teori terkait? Elemen apa sajakah yang harus hadir pada sebuah smart library?

Penelitian ini bertujuan menjawab pertanyaan tersebut dengan menggunakan empat perpustakaan perguruan tinggi di atas sebagai studi kasus. Kehadiran fasilitas cerdas yang telah digunakan di empat perpustakaan perguruan tinggi tersebut dievaluasi dengan membandingkan kelengkapan fasilitas tersedia dengan kelengkapan menurut standar literatur elemen-elemen smart library.

\section{METODE}

Metode yang digunakan adalah metode deskripsi komparatif yaitu meneliti kondisi obyek ilmiah dengan cara membandingkan dan mendeskripsikan data yang didapat melalui observasi dengan data literatur (Naibaho et al., 2016). Dalam melakukan penelitian ini diperlukan data-data dan informasi yang lengkap, relevan serta jelas. Untuk mengumpulkan bahan-bahan serta mendapatkan data yang berhubungan langsung dengan penelitian dilakukan peninjauan langsung yang meliputi:

1. Observasi

Observasi dilakukan di 4 Lokasi yaitu Perpustakaan Universitas Telkom, Perpustakaan UIN Bandung, Perpustakaan ITB, dan Perpustakaan Widyatama. Kegiatan yang dilakukan yaitu mengamati dan mendokumentasikan keadaan di area objek penelitian. Observasi dilakukan dengan tujuan untuk memperoleh data-data dan informasi untuk menganalisis objek penelitian.

2. Wawancara

Wawancara dilakukan kepada staff Perpustakaan Open Library Tel-U, Perpustakaan UIN Sunan Gunung Djati Kampus 1 Kota Bandung, Perpustakaan ITB, dan Perpustakaan Universitas Widyatama untuk mengetahui fasilitas cerdas dan sistem yang digunakan di perpustakaan.
3. Literatur

Data literatur yang digunakan pada penelitian ini diambil dari buku dan jurnal tentang konsep Smart Library.

\section{PEMBAHASAN}

1. Smart Library

\subsection{Definisi Smart Library}

Smart library menurut Wang (2013) adalah sebuah konsep dan praktik pembangunan berkelanjutan dari perpustakaan modern. Konsep dan praktik ini menurut Wang (2013) berbasis pada teknologi informasi digital cerdas dan berjejaring dengan interkoneksi, efisiensi dan kenyamanan tinggi sebagai fitur utama. Tak luput pula konsep pengembangan berkelanjutan dan layanan digital untuk masyarakat umum sebagai kejaran utama.

Untuk meningkatkan performa perpustakaan, Joachim Schöpfel (2018) menyebutkan bahwa perpustakaan yang modern dengan fasilitas Smart Library dapat meningkatkan kualitas layanan, mengembangkan layanan baru, dan menerapkan teknologi informasi baru. Konsep Smart Library berkaitan dengan digital library karena keduanya samasama berbasis pada digitization dan networking, akan tetapi dalam Smart Library sudah dikombinasikan dengan intelligence technology, keberagaman budaya, dan interaksi sosial, smart library bukan sekedar perluasan perpustakaan secara fisik akan difokuskan pada layanan prima perpustakaan dan manajemen berkualitas tinggi dengan dukungan Teknologi Informasi (Hardi, 2017).

Smart Library memiliki 4 elemen dalam konsepnya, diantaranya smart service, smart place, smart governance, dan smart people (Schöpfel, 2018). Smart Service yaitu menghadirkan inovasi teknologi sebagai layanan cerdas, seperti RFID, akses seluler dan nirkabel, bantuan jarak jauh, web semantik. Lalu, smart people adalah mirip dengan konsep perpustakaan hijau yang mencangkup kepatuhan terhadap sistem peringkat bangunan berkelanjutan, pengelolaan limbah, daya tarik kondisi alam, kurangnya polusi, dan pengelolaan sumber daya berkelanjutan, dll. Sementara itu, smart governance 
mencakup semua fitur perpustakaan yang sesuai dengan konsep "tata kelola yang cerdas" misalnya, kolaborasi, kerja sama, kemitraan, keterlibatan warga negara, dan partisipasi masyarat. Dan terakhir smart people merupakan konsep pengguna cerdas tidak hanya mencakup warga negara yang cerdas, pengguna layanan perpustakaan cerdas, tetapi juga staff perpustakaan, keterampilan mereka, dan pengembangan pekerjaan.

Sementara itu, menurut Moon et al (2014), Smart Library adalah sistem inovatif yang mengadopsi teknologi informasi terkini dan sistem layanan yang ditingkatkan dari sudut pandang budaya perpustakaan baru (Moon et al., 2014).

Hal tersebut berpengaruh pada:

- Knowledge resource network

Sumber daya pengetahuan yang beragam telah baru muncul dan sumber daya tradisional diubah menjadi bentuk digital.

- Library social network

Sistem perpustakaan harus memainkan peran hub jaringan sosial untuk menyediakan kegiatan pengetahuan dan partisipasi bisnis pengguna.

- Smart service network

Sistem perpustakaan harus memiliki fungsi perolehan informasi yang efisien untuk bisnis mereka sendiri serta menawarkan layanan cerdas di mana-mana melalui perangkat cerdas. Untuk realisasi layanan perpustakaan cerdas, komputasi cloud yang merupakan infrastruktur penting untuk mengembangkan layanan yang berkelanjutan.

- Technology network

Menghadirkan layanan cerdas dan komputasi di mana-mana untuk pengelolaan sumber daya informasi yang efisien. Selain itu, teknologi jaringan canggih digunakan untuk infrastruktur sistem informasi perpustakaan.

Dalam sistem smart building pun melibatkan berbagai instalasi dan penggunaan kecanggihan dan terintegrasi dalam system teknologi bangunan. Sistem ini mencakup otomatisasi bangunan, keamanan, telekomunikasi, sistem pengguna, dan sistem manajemen fasilitas (Mannan \& Muchlis, 2012). Sistem Smart
Building merupakan gabungan antara teknologi dan pelayanan yang dikhususkan pada lingkungan rumah atau gedung dengan fungsi tertentu yang bertujuan meningkatkan efisiensi, kenyamanan dan keamanan penghuninya (Usmanto \& Susilowati, 2017).

Menurut Surachman (2006), konsep smart library berhubungan dengan digital library karena keduanya tercakup dalam digitization dan networking, akan tetapi smart library sudah terhubung dengan intelligence technology, keberagaman budaya, dan interaksi sosial. Smart library terintegrasi pada layanan prima perpustakaan dan manajemen berkualitas tinggi dengan dukungan Teknologi Informasi (Surachman, 2016). Hal ini direpresentasikan dengan interkoneksi, efisiensi yang tinggi dan kenyamanan (Wang, 2013). Smart Library merupakan bagian dari "Intelligence Library" yang erat kaitannya dengan penerapan konsep Library 3.0. Hal-hal yang perlu diperhatikan pada konsep Smart Library diantaranya:

\section{Smart Technology}

Smart Library dapat memfasilitasi teknologi cerdas di perpustakaan. Teknologi cerdas merupakan perangkat keras maupun perangkat lunak serta perangkat pendukung yang lain. Perangkat keras yang digunakan diantaranya penggunaan perangkat nirkabel, RFID dan mobile devices dalam pelayanan di perpustakaan. Selain itu, penggunaan teknologi berbasis smart untuk multimedia dapat menggunakan Smart TV sebagai media akses interaktif dan dinamis bagi para pemustaka. Pemanfaatan teknologi e-money dan pembayaran non-tunai merupakan salah satu contoh untuk pemanfaatan teknologi cerdas di perpustakaan. Pada sisi aplikasi, aplikasi berbasis mobile masih menjadi satu ciri yang paling utama, namun aplikasi yang saling terkoneksi, terintegrasi dan berbasis jaringan global menjadi sisi penting lainnya. Penggunaan teknologi berbasis Augmented Reality, GPS Locations, Games, dan artificial intelligence menjadi hal penting untuk dipertimbangkan dalam peningkatan Smart Library.

\section{Smart Environment}

Smart Environment merupakan pembentukan lingkungan cerdas yang diawali dengan pola dan strategi 
pengelolaan perpustakaan yang fleksibel, adaptif, mudah untuk dikembangkan, dan mengikuti pola perilaku pemustaka. Lingkungan cerdas akan bertugas untuk membentuk satu kelompok cerdas di perpustakaan. Pengembangan lingkungan cerdas dapat dirancang melalui desain interior perpustakaan, desain sistem, desain prosedur atau proses bisnis, infrastruktur hingga kepada desain gedung perpustakaan. Perencanaan terhadap keempat hal tersebut sangat penting untuk menciptakan satu lingkungan yang dapat menciptakan sebuah kelompok cerdas di perpustakaan.

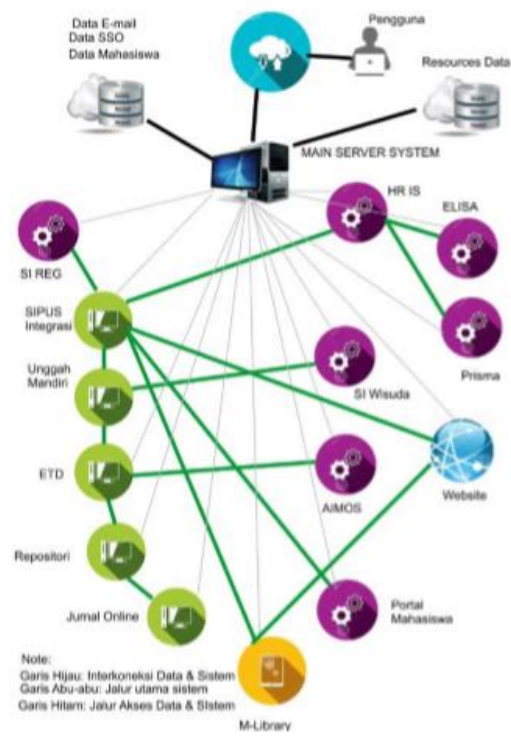

Gambar 1. Ilustrasi Interkoneksi Sistem Informasi di Universitas Gadjah Mada

Sumber : Surachman (2016)

Salah satu contoh penerapan smart environment yaitu pada perpustakaan Universitas Gadjah Mada (Surachman, 2016). Garis berwarna hitam pada Gambar 1 merupakan akses utama untuk data dan sistem berasal (dari pengelola yang mengatur seluruh data yang diperlukan untuk dimasukkan kedalam sistem digital), kemudian garis abu-abu merupakan penyalur dari sistem utama yang bergaris hitam menuju garis hijau yang merupakan interkoneksi/koneksi lanjutan yang dibutuhkan pengguna seperti mengakses repositori daring, buku digital, sistem peminjaman mandiri, dan kebutuhan lainnya.

\section{Smart Service}

Smart Service dapat menyediakan fasilitas yang dapat memudahkan pengguna dalam mengakses fasilitas. Pemanfaatan alert system sebagai salah satu contoh fasilitas yang dapat digunakan pemustaka dengan mengatifkan notifikasi peminjaman koleksi, denda, layanan terbaru, pemesanan buku dan informasi layanan pribadi lainnya dengan menyambungkannya melalui e-mail, sms, mobile apps account, maupun social media. Dengan adanya hal tersebut, dapat memudahkan pemustaka untuk berkomunikasi dengan pustakawan atau pengelola perpustakaan terkait layanan perpustakaan.

Pelayanan berbasis sumber daya digital dan jejaring global juga menjadi faktor penting dalam smart library. Pemanfaatan single account untuk dapat mengakses berbagai sumber daya digital kapanpun dan dimanapun yang dimiliki oleh perpustakaan harus menjadi bagian yang tidak terpisahkan dalam layanan cerdas perpustakaan. Smart services perlu didukung dengan fasilitas smart technology, smart environment, smart communities dan smart librarians.

\section{Smart Communities/User}

Smart Library akan membentuk sebuah kelompok pengguna cerdas (smart users) yang secara cepat dapat beradaptasi dengan perubahan orientasi cara perpustakaan dalam melayani mereka. Smart Communities/Users merupakan kelompok yang siap menggunakan dan memanfaatkan fasilitas smart technology, smart services dan beradaptasi dengan smart environment yang ada di perpustakaan. Generasi digital natives merupakan kelompok yang sangat siap sebagai smart communities. Kebiasaan mereka memanfaatkan smart devices, intensitas interaksi sosial, berjejaring, dan perilaku yang tidak dapat lepas dari teknologi menjadi kekuatan dari smart communities.

\section{Smart Librarian/Staff}

Komponen lain selain keberadaan smart communities adalah kemampuan pustakawan atau staf perpustakaan dalam menggunakan fasilitas smart library. Pustakawan pun perlu memiliki keahlian dalam pemanfataan berbagai perangkat cerdas, mengetahui kebutuhan pemustaka dari generasi digital, mengerti pola perilaku pemustaka, dan harus meluangkan waktu lebih untuk selalu siap memberikan layanan kepada pemustaka dan juga 
meningkatkan pengetahuannya. Selain memberikan pelayanan, maka pustakawan perlu memposisikan dirinya sebagai pembimbing, konsultan, bahkan pendamping pemustaka dalam melakukan eksplorasi terhadap pengetahuan dan informasi yang dibutuhkan.

Smart Library pada era ini, segala aktivitasnya dilakukan dengan cara memanfaatkan eksistensi dari sebuah teknologi, yang mengedepankan proses otomasi dan pertukaran data secara langsung berupa konektivitas antara manusia, mesin dan data yang tercakup didalam Internet of Thing maupun Artificial Intelligence dengan perpaduan antara teknologi robotik maupun sensor dengan memanfaatkan eksistensi internet sebagai penghubungnya (Al Alim Manurung, 2019). Konsep ini dituangkan AL Alim Manurung (2019) pada Bagan 1 di bawah ini yang menyebutkan elemen smart library berupa layanan informasi cerdas, waktu sebenarnya (realtime), pencarian cerdas, internet of thing, global positioning system (GPS).

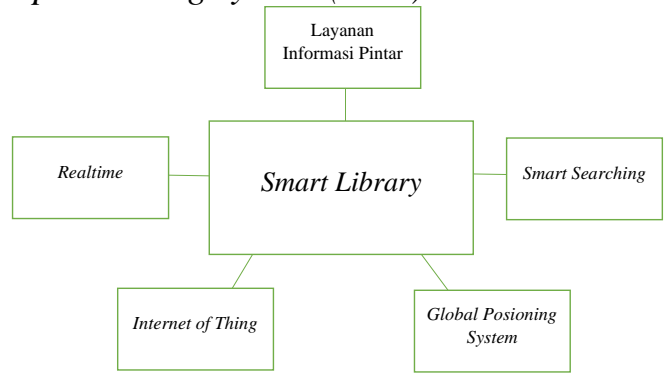

Bagan 1. Konsep Smart Library menurut Al Alim Manurung

Sumber: Jurnal Implementasi Smart Library menggunakan konsep Internet of Thing dalam

Meningkatkan Pelayanan Perpustakaan

Smart Library memiliki 4 konsep yaitu, Smart Place, Smart Governance, Smart Service, dan Smart People (Schöpfel, 2018). Smart place merupakan konsep smart living yang bergantung pada smart technology untuk kelestarian lingkungan dalam penghematan energi (menuju green library). Sementara itu, Smart governance merupakan hubungan antar jaringan internet ataupun aplikasi teknologi informasi pada satu pusat yang dapat berhubungan ke seluruh pengguna serta pada suatu fasilitas yang menggunakan suatu sistem tertentu. Smart service yaitu penggunaan perangkat keras (hardware) serta perangkat lunak (software) sebagai penunjang fasilitas perpustakaan dalam penggunaan nirkabel, RFID, dan mobile device yang terhubung dengan fasilitas berteknologi salah satunya mengembangkan self service pada perpustakaan. Terakhir, smart people adalah pengguna perpustakaan baik pemustaka dan pustakawan yang mampu beradaptasi dalam menggunakan teknologi seperti pemanfaatan dalam penggunaan single account dan alert system dengan memfasilitasi fasilitas pelatihan terlebih dahulu. Konsep tersebut digambarkan Schöpfel (2018) seperti pada Bagan 2 berikut ini.

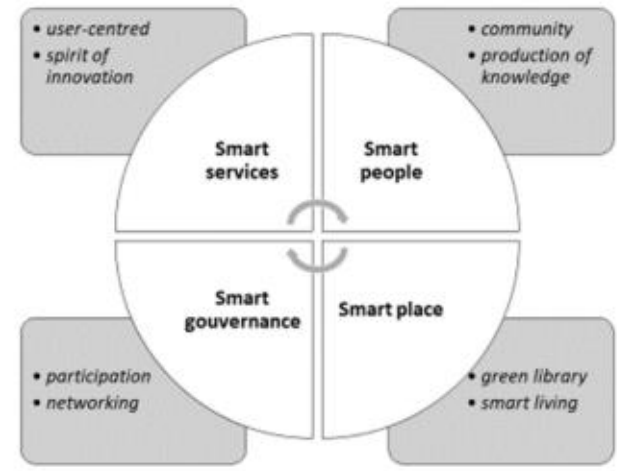

Bagan 2. Konsep Smart Library

Sumber: Jurnal Smart Libraries by Joachim Schöpfel

\subsection{Fasilitas Smart Library}

Chan \& Chan (2018) menyebutkan bahwa Smart Library harus memiliki fasilitas yang mudah digunakan, fleksibel, dan terintegrasi menggunakan sebuah sistem atau teknologi. Secara rinci Chan \& Chan menyebutkan kelengkapan fasilitas smart library berikut tujuan dan fitur yang ada. Kelengkapan tersebut ditampilkan pada Tabel 1 berikut ini.

Tabel 1. Fasilitas Smart Library (Chan \& Chan, 2018)

\begin{tabular}{ll}
\hline Fasilitas Smart & Tujuan dan Fitur yang Ada \\
Library & \\
\hline Pengaplikasian & - Tag RFID disetiap buku, \\
RFID & Pelacakkan RFID saat \\
& memasukki/keluar perpustakaan \\
& untuk keamanan, \\
& - RFID berguna untuk menghitung \\
& jumlah pengunjung yang masuk, \\
& dan sebagai statistic panel grafis. \\
& - Mengetahui buku yang sedang \\
& dipinjam atau buku yang tersedia \\
& di rak buku menggunakan \\
& barcode/chip, \\
Rak Buku Cerdas & Pelayanan buku secara mandiri,
\end{tabular}




\begin{tabular}{|c|c|}
\hline & $\begin{array}{l}\text { - Pelacakkan dan pemantauan } \\
\text { buku secara langsung dan } 24 \\
\text { jam, } \\
\text { - Penelusuran buku dapat melalui } \\
\text { layanan monitor, } \\
\text { - Sinyal pendeteksi jika terjadi } \\
\text { kesalahan dalam penyimpnan } \\
\text { buku. }\end{array}$ \\
\hline 24 Jam Self-Service & $\begin{array}{l}\text { - Terintergrasi melalui RFID, } \\
\text { - Pengembalian buku secara } \\
\text { otomatis melaui program, } \\
\text { - Dapat mengetahui jika ada } \\
\text { keterlambatan pengembalian } \\
\text { buku atau adanya kerusakkan } \\
\text { buku atau adanya kehilangan } \\
\text { buku dapat terdeketsi, } \\
\text { - Memperpanjang buku dengan } \\
\text { mandiri. }\end{array}$ \\
\hline Loker Cerdas & $\begin{array}{l}\text { - Menggunakan RFID, atau } \\
\text { barcode untuk menggunakan } \\
\text { fasilitas loker, } \\
\text { - Akan terdeteksi loker yang } \\
\text { sedang diisi dan tidak diisi. }\end{array}$ \\
\hline Fasilitas Robotik & $\begin{array}{l}\text { - Robot bergerak otomatis untuk } \\
\text { memudahkan navigasi dengan } \\
\text { membangun peta, mengatur } \\
\text { lokasi dan menavigasi ke lokasi } \\
\text { target dan melakukan stock take, } \\
\text { - Akan dilengkapi dengan layar } \\
\text { sentuh dan sistem pengenalan } \\
\text { suara, } \\
\text { - Dapat mengidentifikasi buku } \\
\text { yang hilang dan memeriksa buku } \\
\text { tempat yang salah kemudian } \\
\text { menghasilkan laporan untuk } \\
\text { pustakawan untuk mengambil } \\
\text { tindakan lebih lanjut. }\end{array}$ \\
\hline $\begin{array}{l}\text { Drop dan Sortir } \\
\text { Buku }\end{array}$ & $\begin{array}{l}\text { - } \text { Pembaharuan setiap } 24 \text { jam, } \\
\text { - Meningkatkan efisiensi } \\
\text { perpustakaan dengan otomatis } \\
\text { melalui program, } \\
\text { - Membantu dan memudahkan } \\
\text { pustakawan dalam bekerja } \\
\text { melaui } \\
\text { teknologi/program. }\end{array}$ \\
\hline $\begin{array}{l}\text { Pemesanan ruang } \\
\text { menggunakan } \\
\text { sistem }\end{array}$ & $\begin{array}{l}\text { - Pemesanan fasilitas perpustakaan } \\
\text { secara online seperti ruang serba } \\
\text { guna dan peralatan multimedia, } \\
\text { - Layar cerdas untuk menampilkan } \\
\text { nama pengguna dan detail } \\
\text { pemesanan pada tag untuk } \\
\text { pemesanan ruang fungsi dan } \\
\text { sudut studi, } \\
\text { - Dukungan untuk kode QR, } \\
\text { RFID, dan teknologi kartu cerdas } \\
\text { untuk kontrol akses. }\end{array}$ \\
\hline
\end{tabular}

\section{Evaluasi Penerapan Elemen Smart Library pada Objek Studi}

2.1. Deskripsi Objek Studi dan Kelengkapan Fasilitas
Oplib Tel-U

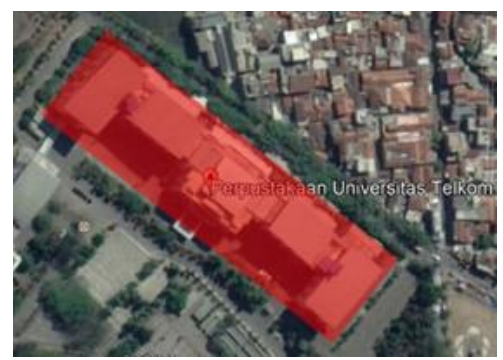

Gambar 1. Site Plan Perpustakaan Universitas Telkom Sumber: Google Earth

Perpustakaan Universitas Telkom berada di Gedung Dekanat tepatnya berada di lantai 5 . Gedung Dekanat ini berada di antara Fakultas Ekonomi Bisnis dan Fakultas Komunikasi Bisnis. Untuk menuju Perpustakaan, di sediakan lift untuk naik ke lantai 5. Kondisi lingkungan perpustakaan tidak begitu banyak dikelilingi pohon rindang, sehingga didalam ruang perpustakaan perlu menggunakan penghawaan buatan. Kondisi ini tampak pada site plan pada Gambar 1 di atas.

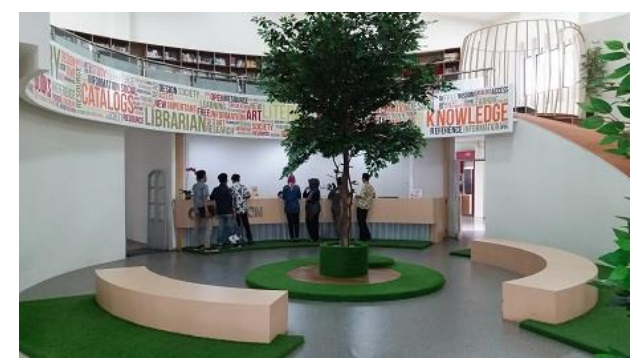

Gambar 2. Area Sirkulasi

Sumber:

https://openlibrary.telkomuniversity.ac.id/home/gallery .html

Fasilitas keseluruhan yang dimiliki Oplib Tel-U diantaranya pada area lantai 1 terdapat area loker biasa, area loker cerdas, area pencarian buku mandiri, area peminjaman buku mandiri, area pintu masuk dan keluar, area resepsionis, area sirkulasi, area multimedia, area penyimpanan buku, area baca terbuka berkelompok kapasitas per-meja 4 orang, area baca individu, area BI Corner, area KPK Corner, Coffee Corner. Area sirkulasi buku dan akses ke lantai 2 tampak pada Gambar 2 di atas.

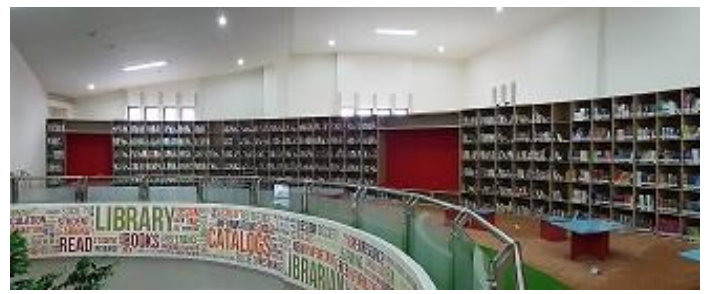

Gambar 3. Penyimpanan buku khusus di Lantai 2 Perpustakaan Universitas Telkom 
Sumber:

https://openlibrary.telkomuniversity.ac.id/home/gallery.h $\underline{\mathrm{tml}}$

Pada area lantai 2 Oplib Tel- $U$ terdapat area diskusi lesehan dan area diskusi berkelompok kapasitas per-meja 4 orang, serta penyimpanan buku khusus (novel, dll). Situasi penyimpanan dan diskusi lesehan tampak pada Gambar 3.

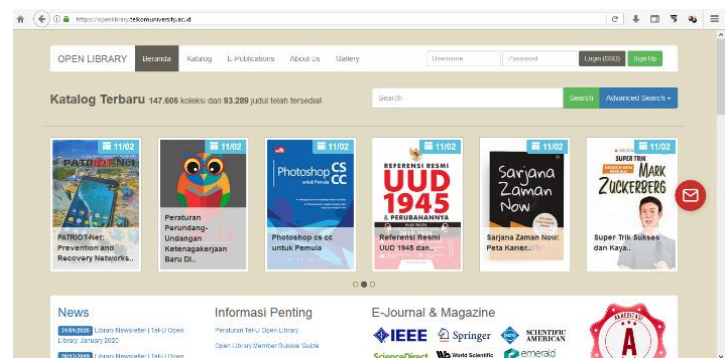

Gambar 4. Website Open Library Telkom

Sumber: https://openlibrary.telkomuniversity.ac.id/

Gambar 4 menunjukkan laman Oplib Tel-U untuk mengetahui buku yang tersedia. Laman ini dapat diakses melalui openlibrary.telkomuniversity.ac.id. yang bisa diakses oleh seluruh mahasiswa menggunakan akun masing-masing, sehingga dapat memudahkan dalam pencarian buku atau kebutuhan lainnya. Laman ini pun berguna untuk melakukan reservasi area diskusi tertutup, memperpanjang peminjaman buku, dan mendata arsip mahasiwa (skripsi dan tugas akhir mahasiswa).

\section{Perpustakaan UIN Sunan Gunung Djati}

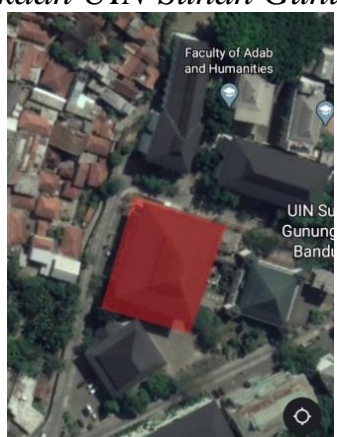

Gambar 5. Site Plan Perpustakaan UIN Bandung Sumber: Google Earth

Universitas Negeri Islam (UIN) Sunan Gunung Djati Kampus 1 berada di Jl. A.H. Nasution No.105, Cipadung, Kec. Cibiru, Kota Bandung, Jawa Barat 40614. Seperti tampak pada Gambar 5, lokasinya dekat dengan perumahan warga setempat dengan minim pepohonan di sekitar perpustakaan UIN, sehingga membutuhkan penghawaaan buatan untuk mengontrol suhu di dalam ruang perpustakaan. Di bagian utara bangunan Perpustakaan UIN terdapat Fakultas Psikologi, dan dibagian belakang Perpustakaan UIN tepatnya di arah barat daya terdapat area parkir serta Aula Abdjan Soelaeman. Di samping kanan perpustakaan tepatnya di arah timur terdapat Mesjid Ikomah.

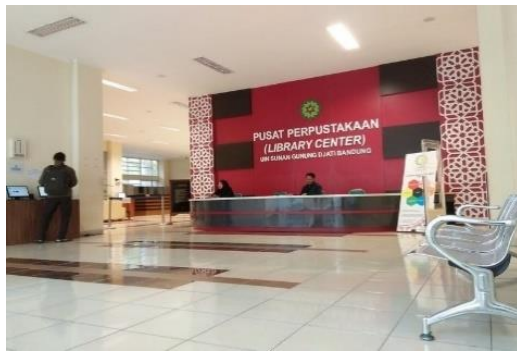

Gambar 6. Area Respsionis Perpustakaan UIN Bandung

Sumber: https://www.quipper.com/id/blog/quippercampus/campus-info/perpustakaan-kece-di-universitasislam-negeri-sunan-gunung-djati/

Perpustakaan UIN memiliki 4 lantai. Pada lantai 1 terdapat lobby, ruang kepala perpustakaan, ruang pengadaan, ruang pengolahan, ruang meeting, ruang seminar, ruang otomasi, ruang tata usaha, ruang bookdrop, BI Corner, dan ruang loker. Pada Gambar 6 tampak lobi perpustakaan. Lantai 2 difungsikan untuk ruang penyimpanan koleksi buku, area baca, ruang sirkulasi, ruang tagging, ruang jurnal, ruang pemeliharaan, ruang bidang pelayanan, ruang bidang kerjasama, ruang penyimpanan buku ASIA foundation.

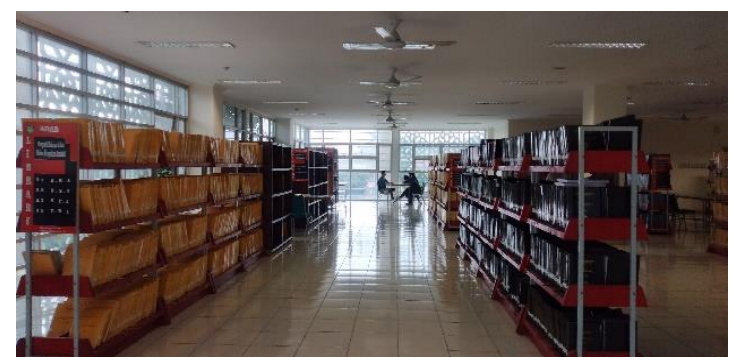

Gambar 7. Rak Buku Besi Perpustakaan UIN Sunan Gunung Djati

Lantai 3 digunakan untuk area referensi, area membaca, ruang pengolahan skripsi dan ruang penyimpanan skripsi. Dan lantai 4 terdapat ruang Aula (Untuk Seminar/Pertemuan Besar). Area penyimpanan buku menggunakan rak buku besi seperti tampak pada Gambar 7.

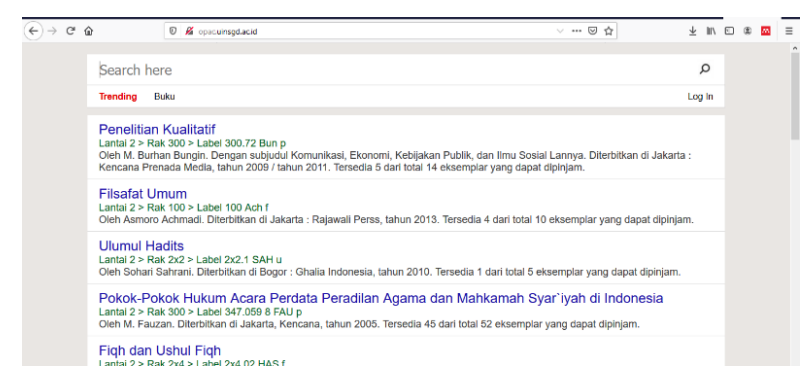


Gambar 8. Layanan OPAC Perpustakaan UIN Sunan Gunung Djati

Sumber: https://lib.uinsgd.ac.id/

Perpustakaan UIN Bandung memiliki layanan via daring, sebagaimana ditampilkan Gambar 8, yang berfungsi untuk pencarian buku dan perpanjang buku secara daring. Layanan ini pun berguna untuk mengetahui profil perpustakaan dan data berapa banyak pengunjung yang datang serta berapa banyak buku yang meminjam ke perpustakaan setiap harinya.

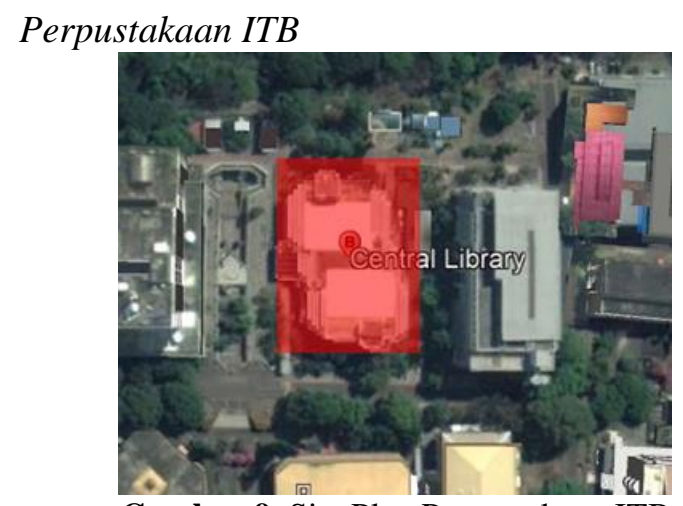

Gambar 9. Site Plan Perpustakaan ITB Sumber: Google Earth

Perpustakaan ITB berada di dekat Gedung Matematika dan Astronomi serta Sekertariat Unit Jepang ITB. Jika dilihat dari site plan pada Gambar 9, bangunan Perpustakaan ITB hampir seluruhnya dikelilingi pepohanan sehingga berpotensi untuk menggunakan penghawaan alami.

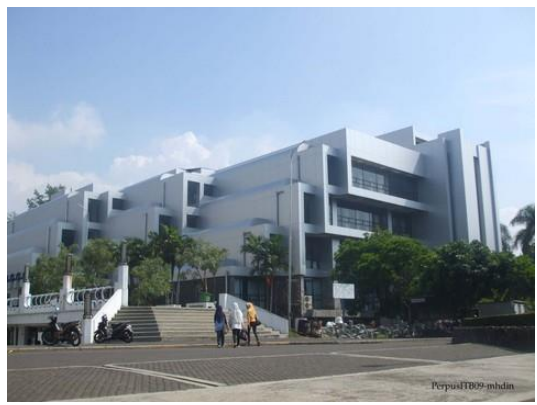

Gambar 10. Fasad Perpustakaan ITB Sumber:

https://www.itb.ac.id/news/read/3775/home/revitalisasigedung-perpustakaan-itb-lebih-nyaman-sebagai-sumberpengetahuan-itb

Perpustakaan ITB memiliki 4 lantai bangunan, seperti tampak pada Gambar 10. Lantai 1 digunakan sebagai area pintu masuk dan keluar, area resepsionis, area penyimpanan loker, ruang American corner, area peminjaman buku, area penyimpanan buku baru \& kerja sama, area diskusi terbuka, dan area baca individu.

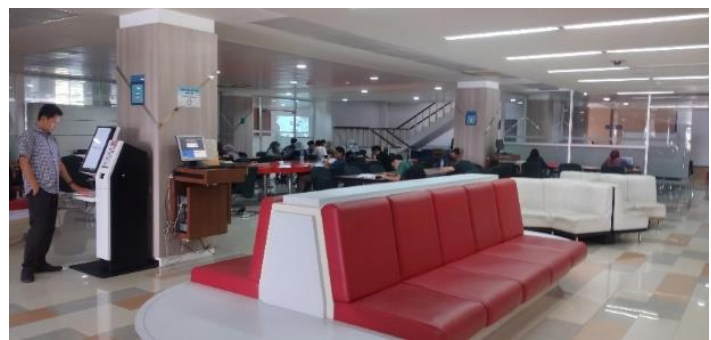

Gambar 11. Fasilitas Lounge Perpustakaan ITB

Area lantai 2 difungsikan untuk penyimpanan katalog, area penyimpanan buku umum kode 500799, penyimpanan buku TPB, area baca terbuka individu, area baca terbuka berkelompok kapasitas per-meja 4 orang, ruang informasi \& pelayanan, ruang server, dan lavatory. Untuk lantai 3 terdapat penyimpanan buku umum kode 000-499 dan 800999, penyimpanan jurnal dan klipping, area baca individu, area baca berkelompok kapasitas 4 orang per-meja, ruang informasi dan fotokopi, ruang majalah. Pada Gambar 11 dapat dilihat fasilitas lounge dengan fasilitas digital di dekatnya.

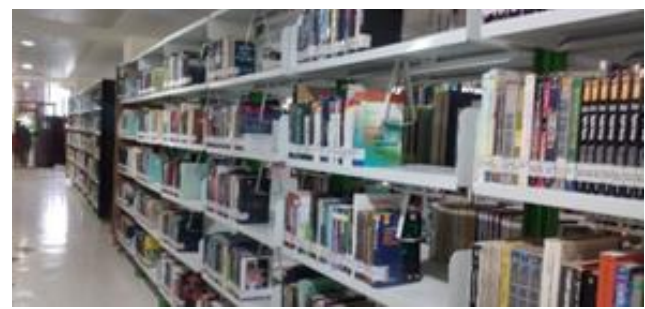

Gambar 12. Penyimpanan Buku Perpustakaan ITB

Lantai 4 difungsikan untuk penyimpanan koleksi rujukan yang tersedia terdiri dari, kamus, ensiklopedia, handbook, manual, direktori, buku tahunan, biografi dan peta. Koleksi rujukan diberi kode R. Adapula penyimpanan buku umum yang merupakan hadiah dari The British Council yang disumbangkan kepada ITB. Koleksi Umum terdiri dari beragam pustaka dalam bahasa Inggris dan Indonesia, mulai dari buku-buku khusus untuk anak, remaja, novel, biografi, geografi, budaya, dan sejarah. Dan lantai 4 pun digunakan untuk menyimpan arsip ITB seperti skripsi dan jurnal. Buku disimpan dan diklasifikasi menggunakan rak berderet seperti tampak pada Gambar 12.

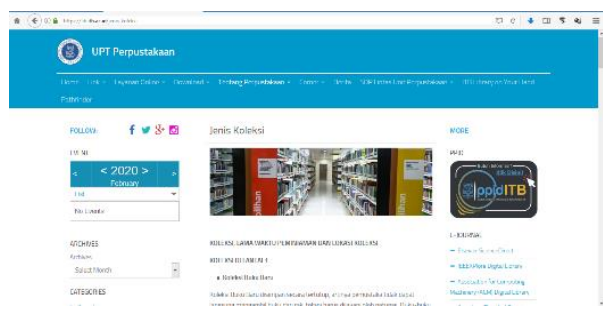

Gambar 13. Unit Pelayanan Online Perpustakaan Sumber: https://lib.itb.ac.id/jenis-koleksi 
Perpustakaan ITB memiliki unit pelayanan daring perpustakaan, seperti tampak pada Gambar 13, yang bisa diakses oleh mahasiswa ITB ataupun non-mahasiswa ITB. Fasilitas daring ini berguna untuk pencarian buku yang akan dituju, dan informasi lainnya seperti identitas perpustastakaan, panduan dan petunjuk perpustakaan.
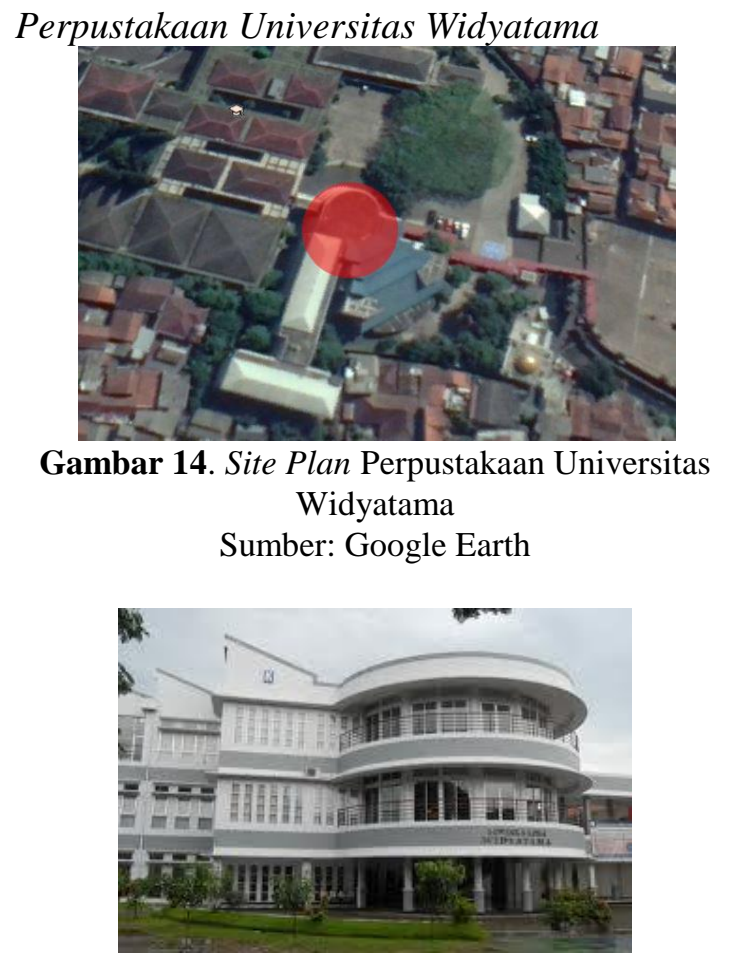

Gambar 15. Fasad Perpustakaan Universitas Widyatama

Sumber: https://perpustakaan.widyatama.ac.id/layananfasilitas-2/

Perpustakaan Universitas Widaytama memiliki 3 lantai. Kondisi lingkungan perpustakaan tidak begitu banyak dikelilingi pohon rindang, tampak pada Gambar 14, sehingga didalam ruang perpustakaan perlu menggunakan penghawaan buatan. Namun jika dilihat dari bentuk bangunan yang tampak pada Gambar 15, Perpustakaan Universitas Widyatama banyak menggunakan pencahayaan alami.

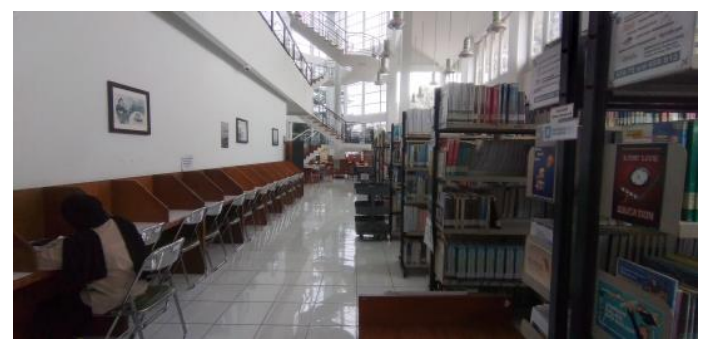

Gambar 16. Area Baca dan Penyimpanan Buku Umum Lantai 1
Perpustakaan Universitas Widayatama memiliki 3 lantai. Lantai 1, tampak pada Gambar 16, digunakan untuk area pintu masuk, area resepsionis, area loker, area audivisual, area baca pengunjung, BI Corner, dan area penyimpanan buku umum. Pada lantai 2, difungsikan untuk area diskusi berkelompok, area audivisual, dan area penyimpanan buku skripsi dan jurnal. Dan lantai 3, dikhusukan untuk aula.

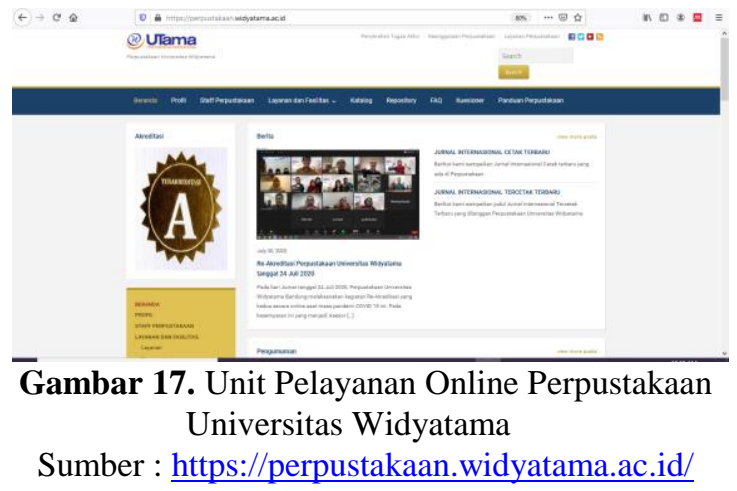

Perpustakaan Universitas Widyatama menyediakan layanan daring, tampak pada Gambar 17, yang dapat diakses oleh mahasiswa menggunakan ID pengguna. Laman ini dapat digunakan untuk mencari buku elektronik (e-book), jurnal elektronik (e-journal), dan untuk mengetahui buku yang dimiliki perpustakaan.

\subsection{Perbandingan Kelengkapan Fasilitas} Smart Library pada Objek Studi Terhadap Standar Literatur

Oplib Tel-U, Perpustakaan UIN Bandung, Perpustakaan ITB, dan Perpustakaan Widyatama memiliki banyak kesamaan pada pemenuhan fasilitas perpustakaan. Perbandingan kelengkapan fasilitas terhadap teori Joachim Schöpfel ditampilkan pada Tabel 2 berikut ini.

Tabel 2. Perbandingan dengan Teori Joachim Schöpfel

\begin{tabular}{lcccc}
\hline \multirow{2}{*}{$\begin{array}{c}\text { Teori } \\
\text { Joachim } \\
\text { Schöpfel }\end{array}$} & \multicolumn{4}{c}{ Objek Penelitian Perpustakaan } \\
\cline { 2 - 5 } & Tel-U & $\begin{array}{c}\text { UIN } \\
\text { Bandung }\end{array}$ & ITB & $\begin{array}{c}\text { Universitas } \\
\text { Widyatama }\end{array}$ \\
\hline $\begin{array}{l}\text { Smart Place } \\
\text { Smart }\end{array}$ & $\mathrm{V}$ & $\mathrm{V}$ & $\mathrm{V}$ & $\mathrm{V}$ \\
$\begin{array}{l}\text { Governance } \\
\text { Smart Service }\end{array}$ & $\mathrm{V}$ & $\mathrm{V}$ & $\mathrm{V}$ & $\mathrm{V}$ \\
Smart People & $\mathrm{V}$ & $\mathrm{V}$ & $\mathrm{V}$ & $\mathrm{V}$ \\
\hline Keterangan: V (sudahy tersedia) & $\mathrm{V}$ & $\mathrm{V}$ & $\mathrm{V}$ \\
\hline
\end{tabular}

Keterangan: V (sudah tersedia), - (belum tersedia)

Jika dibandingkan dengan Teori Joachim Schöpfel, yang membedakan fasilitas Smart Library yang ada pada Oplib Tel-U, Perpustakaan 
UIN Bandung, Perpustakaan ITB, dan Perpustakaan Widyatama yaitu pengadaan fasilitas Smart Service pada Perpustakaan. Persamaan yang dimiliki dari keempat perpustakaan yang pertama, smart place dengan memanfaatkan pencahayaan alami untuk area baca tetapi beberapa ruang perlu menggunakan pencahayaan buatan karena pencahayaan alami yang masuk ke dalam ruang tidak merata. Kedua, keempat perpustakaan sudah memfasilitasi single account untuk setiap pengguna yang ada di kampus agar dapat mengakses fasilitas perpustakaan baik untuk melakukan inputing RFID card saat memasukkin perpustakaan, peminjaman buku, pengembalian buku, dan reservasi online. Dan terakhir, dari 4 perpustakaan yang diteliti sudah memiliki fasilitas pendukung untuk smart people dengan melakukan sosialisasi penggunaan fasilitas perpustakaan bagi mahasiswa baru saat masa orientasi kampus.

Perbandingan pengaplikasian fasilitas Smart Library pada objek penelitian melalui teori Chan \& Chan adalah sebagai berikut.

Tabel 3. Perbanding dengan Teori Chan \& Chan

\begin{tabular}{|c|c|c|c|c|}
\hline \multirow{2}{*}{$\begin{array}{c}\text { Teori Chan \& } \\
\text { Chan }\end{array}$} & \multicolumn{4}{|c|}{ Objek Penelitian Perpustakaan } \\
\hline & Tel-U & $\begin{array}{c}\text { UIN } \\
\text { Bandung }\end{array}$ & ITB & $\begin{array}{c}\text { Universitas } \\
\text { Widyatam } \\
\text { a }\end{array}$ \\
\hline Pengaplikasian & $\mathrm{V}$ & $\mathrm{V}$ & V & $\mathrm{V}$ \\
\hline \multicolumn{5}{|l|}{ RFID } \\
\hline Rak Buku Cerdas & - & - & - & - \\
\hline 24 Jam Self Service & $\mathrm{V}$ & $\mathrm{V}$ & V & $\mathrm{V}$ \\
\hline Loker Cerdas & $\mathrm{V}$ & - & - & - \\
\hline Fasilitas Robotik & - & - & - & - \\
\hline Drop dan sortir & - & - & - & - \\
\hline \multicolumn{5}{|l|}{ buku } \\
\hline Pemesanan Ruang & $\mathrm{V}$ & - & - & - \\
\hline \multicolumn{5}{|l|}{ Menggunakan } \\
\hline Sistem & & & & \\
\hline
\end{tabular}

Apabila keempat objek yang diteliti dibandingkan dengan teori Chan \& Chan, persamaannya adalah belum adanya fasilitas rak buku cerdas dan fasilitas robotik, disebabkan belum tersedianya produk di kota Bandung. Selain itu, perlu dipertimbangkan jumlah biaya yanga akan dikeluarkan. Sementara itu, kesamaan fasilitas yang dimiliki diantaranya sudah menggunakan RFID untuk memasukki perpustakaan sebagai data input masuk menuju perpustakaan bagi penggunanya. Terdapat pula fasilitas 24 jam self-service dengan memanfaatkan website yang dimiliki oleh setiap perpustakaan dan dapat digunakan untuk mengakses e-journal, $e$ book, dan memperpanjang buku secara daring.

Perbedaan yang dimiliki keempat perpustakaan adalah fasilitas loker cerdas. Oplib Tel-U sudah menyediakan walaupun belum seluruhannya menggunakan RFID. Sementara itu ketiga perpustakaan lainnya belum menyediakan fasilitas tersebut. Oplib Tel-U pun sudah menyediakan fasilitas reservasi online melalui website perpustakaan untuk memesan tempat area diskusi tertutup.

Penggunaan RFID mempengaruhi tata ruang perpustakaan dengan meniadakan pintu dan menggantinya dengan akses berupa gate dengan tapping. Model akses ini memiliki dimensi lebih besar daripada pintu biasa, sehingga membutuhkan dimensi ruang lebih besar.

Sementara itu, pengadaan fasilitas pemesanan ruang rapat terjadwal secara daring melalui laman perpustakaan menciptakan efisiensi penggunaan ruang dimana setiap ruang tersedia digunakan secara optimal. Dengan demikian, dapat dihindari penyediaan ruang berlebih karena frekuensi penggunaan telah diatur secara komunal.

Kehadiran laman situs dan layanan 24 jam mempercepat pencarian buku yang dibutuhkan, sehingga pengunjung dapat menggunakan waktu di perpustakaan secara efektif. Hal ini mengurangi antrian dan waktu tunggu di perpustakaan.

\section{KESIMPULAN}

Standar fasilitas smart library harus memperhatikan elemen kelengkapan Chan \& Chan dan konsep smart Joachim Schöpfel. Kedua standar teori merupakan standar ideal sebuah fasilitas agar dapat dikatakan memenuhi kualifikasi smart library.

Pada kenyataanya, perpustakaan yang menyatakan diri sebagai smart library masih belum mampu memenuhi elemen standar fasilitas tersebut. Bahkan Oplib Tel-U, yang paling banyak memiliki elemen smart library berdasarkan standar Chan \& Chan, hanya mampu memenuhi standar kurang dari $60 \%$ (4 dari 7 standar fasilitas). Hal ini terjadi karena keterbatasan finansial dalam pengadaan fasilitas-fasilitas pelengkap smart library tersebut.

Sementara itu, konsep smart yang diutarakan Joachim Schöpfel pun belum semua teraplikasi secara optimal karena berbagai keterbatasan. Konsep yang belum teraplikasi secara nyata 
diantaranya smart place yang terkait dengan smart building.

Dapat dikatakan bahwa merancang sebuah perpustakaan dengan berbasis smart library, harus memperhatikan 4 konsep smart library yang diutarakan oleh Joachim Schöpfel yang diantaranya Smart Place, Smart Governance, Smart Service, dan Smart People. Jika diamati dari objek yang diteliti dan dibandingkan dengan teori Chan \& Chan, elemen fasilitas cerdas yang sudah bisa digunakan pada perpustakaan, yaitu, pengaplikasiaan RFID, 24 jam selfservice, drop dan sortir buku, loker cerdas dan pemesanan ruang menggunakan sistem. Hal sulit untuk diaplikasikan diantaranya penggunaan rak buku cerdas dan fasilitas robotik dikarenakan belum tersedianya fasilitas dan perlu mempertimbangkan anggaran yang dikeluarkan oleh perpustakaan dalam pengggunaan fasilitas cerdas.

\section{DAFTAR PUSTAKA}

Al Alim Manurung, M. K. (2019). Implementasi SMART LIBRARY menggunakan konsep inernet of thing dalam meningkatkan pelayanan perpustakaan. IQRA : Jurnal Ilmu Perpustakaan Dan Informasi (E-Journal), 13(1), 93-104.

Chan, H. C. Y., \& Chan, L. (2018). Smart Library and Smart Campus. Journal of Service Science and Management, 11(06), 543-564. https://doi.org/10.4236/jssm.2018.116037

Daniel, D. M., Thamrin, D., Rakhmawati, A., Studi, P., Interior, D., Petra, U. K., \& Siwalankerto, J. (2018). Implementasi Konsep SMART-Lib dalam Re-desain Interior Perpustakaan Umum Provinsi Sulawesi Selatan. 6(2), 50-58. http://publication.petra.ac.id/index.php/desai n-interior/article/download/7150/6486

Hardi, R. (2017). Rancang Bangun Sistem Smart Library pada Perpustakaan SMK Airlangga Balikpapan. JST (Jurnal Sains Terapan), 3(2). https://doi.org/10.32487/jst.v3i2.260

Mannan, K. A., \& Muchlis, A. F. (2012). Penerapan Teknologi Smart Building Pada Perancangan Smart Masjid. Journal of Islamic Architecture, 2(2), 78-81. https://doi.org/10.18860/jia.v2i2.2205

Moon, H.-K., Kim, J.-R., Han, S.-K., \& Choi, J.-T. (2014). A Reference Model of Smart Library. October 2014, 80-84. https://doi.org/10.14257/astl.2014.63.16

Naibaho, T. I., Irma, U., \& Hanafiah, M. (2016). Analisa Sirkulasi Ruang Gerak Pengguna pada Area Baca di Perpustakaan Universitas Swasta. 1(3), 283-296.
Schöpfel, J. (2018). Smart Libraries. Infrastructures, 3(4), 43. https://doi.org/10.3390/infrastructures304004 3

Surachman, A. (2016). Perancangan SMART LIBRARY bagi Generasi Digital Natives di Universitas Gadjah Mada. Konferensi Perpustakaan DIgital Indonesia Ke-9, November, 120-133. http://kpdi9.perpusnas.go.id/HTML5/index.ht $\mathrm{ml} \# \mathrm{p}=120$

Usmanto, B., \& Susilowati, T. (2017). Perancangan Prototype Teknologi Smart Building Menggunakan Aruino Berbasis Web Server untuk Mendukung Pembangunan Propinsi Lampung Menju Program Lampung "Smart City." 15.

Wang, S. 2013. "The Resource Sharing and Cooperative Development of Smart Libraries in Asia." Journal of Library and Information Sciences 5 (1): 1-12. https://jila.lib.nccu.edu.tw/wpcontent/uploads/2019/11/82_1.pdf. 